UDK 371.3::811.163.41

Љиљана Е. Петровачки

petrovacki@nscable.net

(Филозофски факултет, Нови Сад - Српски језик и лингвистика)

Милица М. Савић

millysavic@yahoo.com

(Филозофски факултет, Нови Сад - Језик и књижевност, докторанд)

\title{
СТРИП У НАСТАВИ ГРАМАТИКЕ СРПСКОГ ЈЕЗИКА
}

Сажетак: У раду су сагледане могућности илустративног представљања језичких појмова, категорија, принципа и законитости уз помоћ стрипа у настави српског језика. Указано је на начине употребе додатног материјала тог типа у различитим фазама обраде градива из синтаксе, као и на значај примене визуелних средстава за приказивање разноврсних комуникативних ситуација. Истакнута су преимућства таквог методичког приступа за остваривање принципа очигледности у настави, те је презентована одабрана језичка и граматичка грађа о реченичним конструкцијама, моделима и типовима за коју су осмишљене и разрађене апликације у виду репрезентативних стриповних предложака.

Кључне речи: методика наставе српског језика, додатни материјал, стрип, реченичне конструкције.

\section{1. УВОД}

Трагалаштво, као једна од основних карактеристика методике наставе српског језика и књижевности, подразумева то да наставник у школском поучавању градива из језика и граматике, ослонац проналази у дидактичким теоријама и већ афирмисаним методама и поступцима, али је при том пожељно да увек изнова трага за новим облицима рада. Поред тога мора имати у виду да граматику због 
њене наизглед апстрактне природе, ваља представљати очигледно. То још више захтева градиво из синтаксе, најзаступљеније граматичке дисциплине у школским програмима, у којој различите реченичне конструкције, због увиђања њихове структуре и функције, треба презентовати укључивањем у контекст и комуникативне ситуације. Веома је важно да се ученици упознају са њиховом применом и оспособе за њихову самосталну употребу. Како би поменути циљеви били остварени у настави, потребно је у школску праксу уводити такве поступке који ће обраду језичке грађе учинити занимљивијом за ученике и ускладити је са комуникативним потребама у њиховом стварном животу.

\section{2. ИЛУСТРАТИВНО ПРЕДСТАВЉАЊЕ ГРАДИВА}

У процесу моделовања часова из граматике, па и из синтаксе, поред наставних метода и облика рада, значајну улогу имају наставна средства, односно разноврсна техничка помагала и ефекти који се њима постижу, затим уџбеници, приручници и лингвостилистички предлошци различитих типова. Одабиром ученицима интересантних текстова из књижевних дела, представљањем различитих разговора и комуникативних ситуација, односно приказивањем граматичких, тј. синтаксичких појмова у њиховој употреби и указивањем на њихову праву сврху, настава се може обогатити и учинити динамичном и подстицајном.

У методичкој науци је познато да комуникација сликом може увелико помоћи ученику да лакше усвоји школско градиво, док се употреба помоћних визуелних средстава у настави матерњег језика нарочито препоручује приликом обраде сложене синтаксичке грађе. Милија Николић сматра да су визуелна наставна средства, односно 
цртежи, графикони и слике нарочито потребни оним наставним подручјима „која су по садржају рационална и по природи вербална те изискују посебну мисаону концентрацију и брзо замарају ученике,” као што то може бити граматика (Николић 2009: 673). Стога наставну праксу ваља обогатити употребом таквих помоћних средстава и инвентивним илустровањем градива који ће бити у функцији тумачења језичких појава.

Примена слика или приче из стрипа један је од начина да се ти циљеви у настави граматике остваре. Ученици воле да читају стрипове, па то може бити добра мотивација да их придобијемо за учење сложених граматичких јединица. Схваћен као визуелно приповедање, односно својеврстан спој нарације и призора, у коме се помоћу врло мало текста и низа цртежа приказује одређени догађај, стрип за ученике може бити вишеструко подстицајан. Такве слике стимулативно делују на ученике, развијају код њих способност посматрања, увиђања појединости и пружају им могућност да замисле целу ситуацију у којој се збива радња. Зато је техника стрипа нарочито погодна за контекстуализацију градива из синтаксе и визуелно представљање грађе о одређеним типовима реченица који се најчешће појављују у усменом говору. То посебно важи за садржаје о упитним, узвичним, заповедним, модалним, вокативним и другим емотивно обојеним реченицама, за управни говор. Из тог разлога овом приликом промишљамо о подстицајним могућностима употребе стрип-приче или слика у функцији презентовања различитих комуникативних ситуација, те ћемо приказати како се форме стрипа могу интегрисати у часове на којима се обрађује градиво из синтаксе о различитим реченичним конструкцијама, односно њиховим типовима или моделима 


\section{3. МОГУЋНОСТИ МОДЕЛОВАЫА НАСТАВНИХ СИТУАЦИЈА}

Слика и текст у стрипу чине нераздвојну целину, допуњују се, кореспондирају, те пружају визуелни приказ читавог једног контекста. Пажљиво одабрана и добро уклопљена у наставни процес, наративна слика у виду стриповног предлошка има широке могућности примене у обради грађе из синтаксе српског језика. Стрип је, наиме, примењив у различитим типовима и фазама часа: може послужити као подстицај за говорну или писмену вежбу, при чему се од ученика захтева употреба одређених синтаксичких средстава; може представљати извор информација на чијој основи ученик сам уочава одређене синтаксичке појмове, процесе, законитости; а може бити намењен и за синтезу знања из синтаксе стечених применом других наставних метода. Погодан је, дакле, за приказивање различитих догађаја, појава, особа, као и разноврсних комуникативних ситуација, при чему њихов опис или анализа треба да имају пуну практичну целисходност у стицању и обједињавању језичких знања.

Један од важних фактора за успешан рад на часу са таквим додатним материјалом управо је правилан избор предлошка те се при његовом одабиру и креирању изискује поштовање одређених методичких начела. Изабрани стрип треба, дакле, да задовољи извесне критеријуме: психолошке - да слике буду јасне, а текст разумљив и разговетан, као и да садржај за ученике буде интересантан, како би његово тумачење изазивало задовољство ${ }^{1}$ естетске - да слике имају одређену естетску и уметничку вредност; педагошке - да ситуација приказана у стрипу буде примерена узрасту ученика, усклађена са

Тежак Стјепко, говорећи о могућностима примене стрипа у настави, истиче да је „стрип добро направљен онда када читаоца увлачи у свој садржај” (Тежак 2000: $585-602)$. 
етапом њиховог развоја, интересовањима, проблемима, догађајима у породици, школи или суседству, али да при том не обилује непотребним детаљима како ученикова пажња не би била заокупљена њима. Наравно, наставник српског језика не мора имати одлично ликовно умење, па му у креирању предложака могу помоћи надарени ученици или наставник ликовног васпитања.

С обзиром на то да стриповне илустрације садрже елементе изненађења и побуђују код ученика интерес за учење, одлични су аниматори за обнављање већ стеченог знања из граматике и припрему за обраду нове синтаксичке грађе. Стога се стрип може користити y инструкиионо-мотивационој фази рада на часу, а нарочито је погодан за представљање одређених реченичних конструкција које се појављују у управном говору. Тако, на пример, у основној и средњој школи, пре упознавања са новим реченичним типовима, као што су специјалне и безличне реченице, или пак реченице са логичким субјектом, наставник уз помоћ адекватног предлошка из стрипа може подсетити ученике на претходно стечена знања о реченичној типологији с обзиром на њихову комуникативу функцију (обавештење, експресивно обавештење, питање, подстицај, заповест, савет, молба, експресивни став...). Увиђањем функционалних садржаја таквих илустрованих ситуација, ученици се могу свестрано припремити за нове појединости. Будући да чулна радозналост и рецептивна моћ представљају најуниверзалније начине учења, применом стрипа у тој фази рада остварује се њихова напоредност, а резултат је поузданије и примењиво знање ученика. Да би се ученици заинтересовали за рад, понекад је потребно унети дозу хумора, као што је то у следећим кадровима стрипа. Припремљене илустрације имају пожељан комични ефекат. 
Методички коментар:

Активности уз помоћ стрип-секвенце могу бити различите. На основу представљених слика и реплика ученици могу добити различите задатке: да анализирају специфичности предикатских и комуникативних реченице у облачићима, да састављају своје примере кратких дијалошких или монолошких форми представљених ликова, да проширују или трансформишу примере и тако уочавају нијансе у њиховим комуникативним вредностима. 

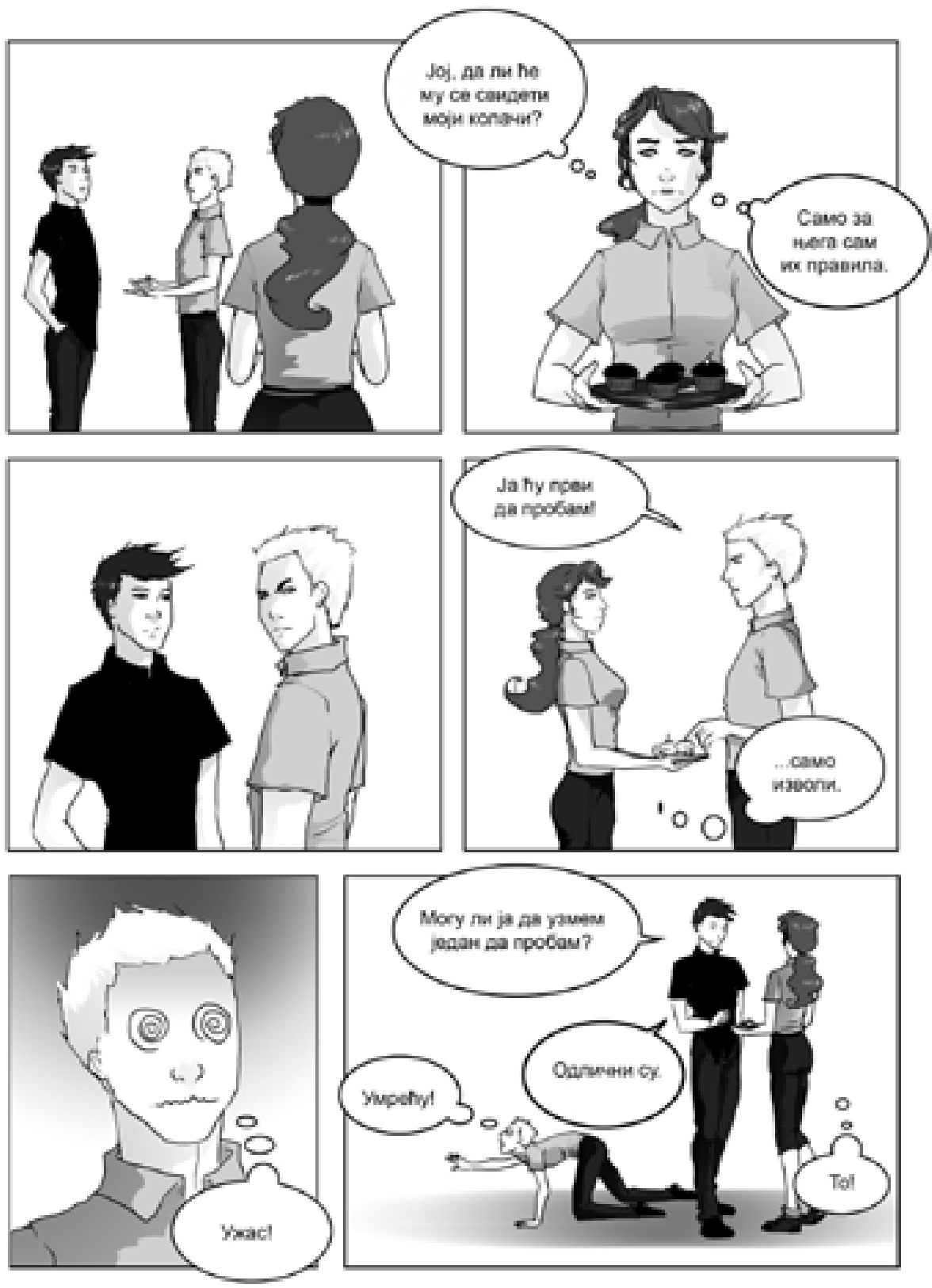

Неопходно је, дакле, унапред испланирати интензивну 
активност на часу и извршити избор материјала за наставни лист који ће стимулисати такву активност.

Стрип се у настави може употребљавати у цеентралном делу часа као полазни текст у функцији тумачења језичких појава које за ученике представљају ново градиво. Треба да буде конципиран тако да уз помоћ визуелних елемената и вербалног дела наводи ученике на самостално закључивање, при чему га, као помоћно средство у настави, ваља користити у спрези са говорном праксом, односно усменом комуникацијом између наставника и ученика. ${ }^{2}$

Будући да је управни говор, као директан израз ситуације коју слика приказује, обично емоционално обојен, такав методички приступ нарочито је згодан у настави синтаксе при представљању посебних реченичних типова, као што су непотпуне или специјалне реченицее. Ради се, наиме, о простим реченицама које не садрже предикат, већ својом синтаксичком конструкцијом чине формулацију поруке, а појављују се увек у посебним комуникативним ситуацијама, па су по форми и значењу прилагођене одређеним експресивним потребама говорника и ситуацијама повишеног емотивног набоја (Пипер и др. 2005: 301; Станојчић, Поповић 1999: 378). ${ }^{3}$ У седмом разреду основне школе ученици стичу основно знање о тим синтаксичким јединицама, док је у четвртом разреду средњих школа програмом предвиђена њихова детаљнија обрада. Како је најважнији циљ изучавања граматичких појмова њихова правилна употреба, ваља их тада посматрати у контексту комуникативних активности, а пошто

\footnotetext{
2 Савремено изучавање граматике искључује трансмисију знања путем предавања и диктирања, па се тако језичке појаве ученику не објашњавају већ се он води да их сам уочава, схвата и образлаже, а усваја их у њиховој практичној функцији оствареној у тексту или живој говорној комуникацији (Илић 2004: 499).

3 Ове реченице се не могу разумети без контекста или ситуације, па стога више припадају јединицама говора, а не реченицама као језичким (граматичким) јединицама (Петровачки 2004: 158-165).
} 
се такве реченице користе најчешће у усменом говору за специјалне експресивне функције, то се најбоље може постићи представљањем странице из стрипа.

Стриповни предложак на коме ће се поменута језичка појава сагледавати може да осликава одређену ситуацију блиску ученицима, тј. њихове свакодневне активности и догађаје у школи, односно различите комуникативне ситуације и дијалоге. Представљањем специјалних реченица на тако интересантан и оригиналан начин наставник ће лаше заинтересовати ученике за њихово изучавање, док ће правила употребе таквих конструкција бити презентована у контекстима дискурса. Материјал треба да буде засићен примерима, па би могао бити осмишљен на следећи начин: 

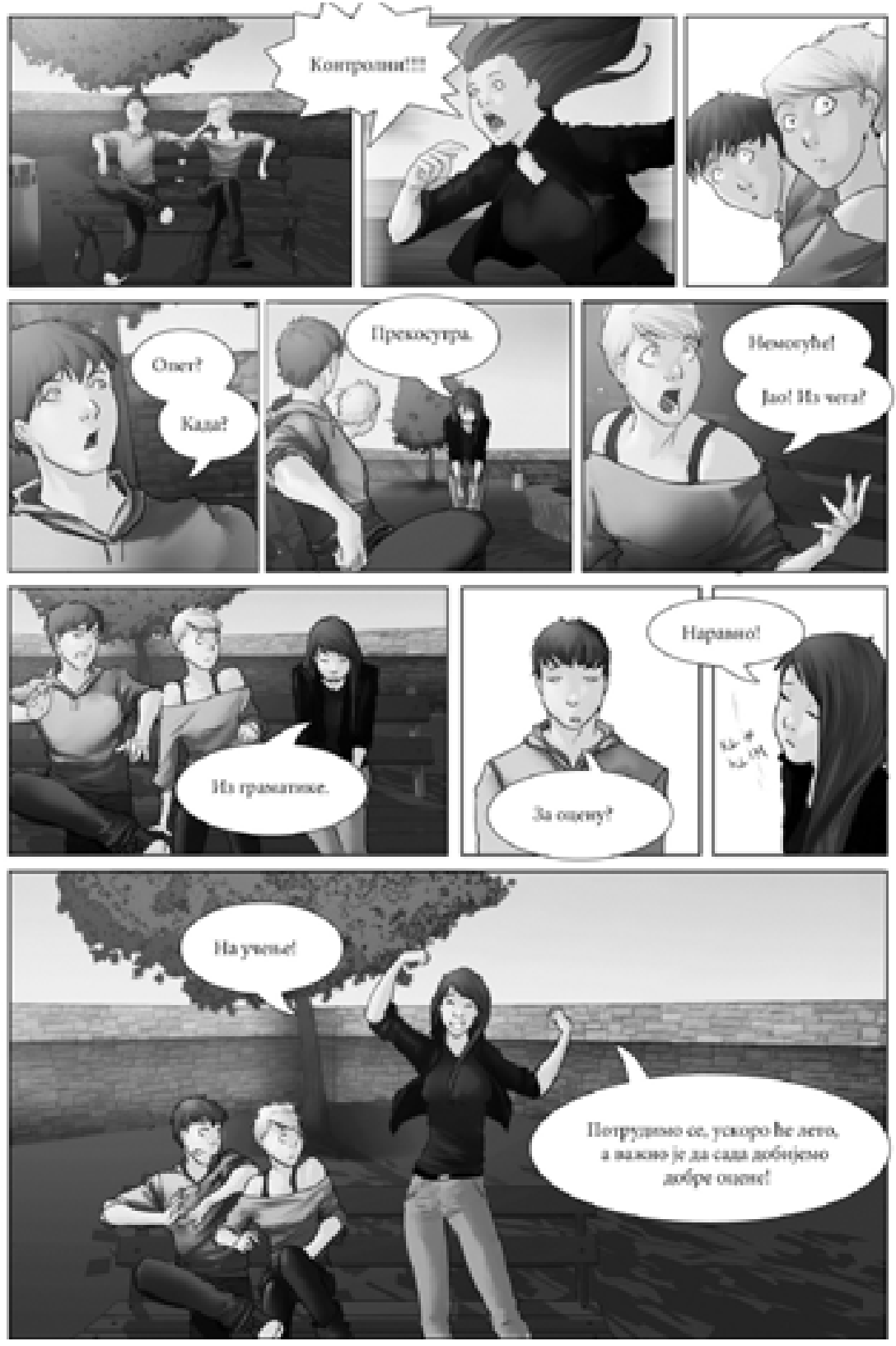

Кроз разговор са наставником и кроз анализу и компарацију примера представљених путем стрипа, ученици могу самостално испитивати својства специјалних реченица, тј. њихове морфолошко- 
синтаксичке и семантичке особености. Важно је да уоче како се у лексичком језгру таквих конструкција не појављује глагол већ друге врсте речи (нпр: Контролни! - придев), да би потом, уз инструкције наставника, могли вршити њихову трансформацију у предикатске реченице (нпр: Наставница је најавила контролни задатак). Увидеће на тај начин да се употребом специјалних и предикатских реченица у усменој комуникацији постижу сасвим другачији ефекти, те да су специјалне реченице емоционално обојене, имају експресивну функцију, а пропраћене су невербалним елементима попут гестова и мимике лица, што је на очигледан начин приказано сликама из стрипа. За сваки од наведених примера могу, затим, одређивати комуникативну функцију (Контролни! Прекосутра! Наравно! Из граматике! - енергично обавештење; Немогуће! - емотивни коментар; Jao! - емотивни узвик; Onет? Из чега? Када? За оцену? - енергично питање; На учење! - заповест). Преимућство оваквог методичког приступа је у томе што применом предлошка у виду стрипа наставник ставља акценат на контекстуализацију градива и његово повезивање са језичком праксом, а тиме и на усаглашавање потреба ученика и садржаја наставе.

У савременој методичкој науци истиче се значај активног коришћења нових појмова из граматике у настави. С тим у вези Павле Илић наводи како се у школској пракси показало да је учење плодније и ефикасније, а знање које се стиче трајно уколико су ученици у могућности да резултате учења примењују у што је могуће више нових и разноврсних ситуација (Илић 1998: 53). Како би показали да су разумели карактеристике специјалних реченица, наставник им може поделити наставни листић са задатком да на стрип сликама препознају и издвоје такве примере. Предложак би могао бити осмишљен на следећи начин: 

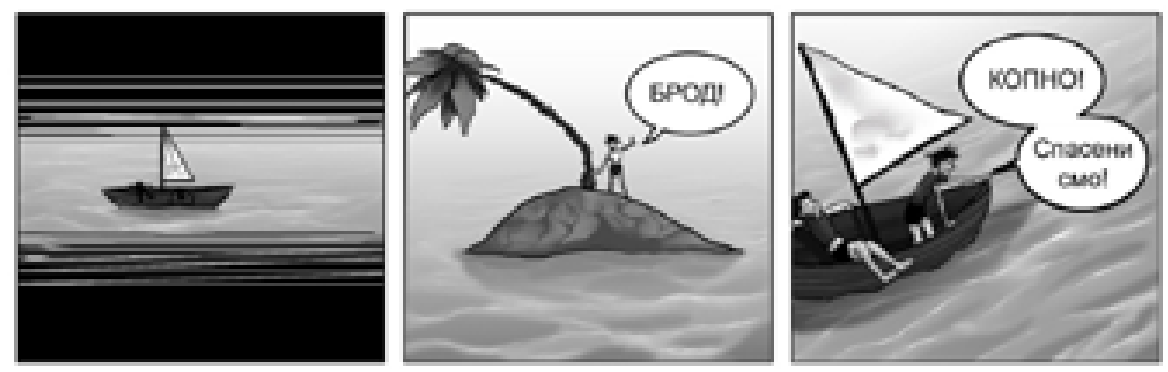

Таквим поступком тестира се рекогниција, односно препознавање специјалних реченица, при чему је тежина задатка прилагођена способностима свих ученика у разреду. Комуникацију и интеракцију уз помоћ поменутих језичких елемената, које ће ученици најпре увидети у стриповним комуникативним моделима на часу, треба потом уочити и у стварним животним ситуацијама. Како би се постигла индивидуализација и захтеви у настави прилагодили способностима сваког појединца, наставник им може дати задатак да самостално осмисле један догађај, односно комуникативну ситуацију у којој ће употребљавати специјалне реченице. У договору са наставником ликовног васпитања ученици би потом на часу ликовне културе могли илустративно, помоћу стрипа, приказати осмишљене говорне ситуације. ${ }^{4}$ Корелацијско-интеграцијским методичким поступцима у повезивању наставе српског језика и ликовног васпитања постижу се важни циљеви наставе - код ученика се тако развијају критичко-аналитичке способности вредновања стрипа, као и способности перципирања, меморисања и уочавања сврхе и намере његове примене у настави српског језика, при чему се богати језички

\footnotetext{
4 Било би добро да им том приликом укратко буду представљени историјат стрипа (дела урбане културе који се зову и девета уметност), његове одлике, односно композиција и низање кадрова, однос слике и текста, као и различити жанрови, стилови, те врсте стрипа и технике његовог креирања.
} 
израз ученика.

Стриповни предложак се, дакле, као вид визуелног представљања градива може користити у дидактичке сврхе у свим фазама рада на часу, па и у његовом завршном делу, приликом утврђивања претходно стеченог знања о одређеним језичким елементима и синтаксичким појмовима. Такав додатни материјал стога може бити врло користан и у фазама синтезе и систематизације градива обрађиваног на више часова. Ученици помоћу разноврсних задатака заснованих на доради стрипа на занимљив начин могу увежбавати различите синтаксичке јединице. Показаћемо то примером који би требало да помогне обнављање ученичких знања о објекту у петом разреду основне школе (Правилник о наставном плану и програму). ${ }^{5}$ Ово градиво је ученицима веома компликовано. ${ }^{6}$ У намери да кроз интересантне вежбе ученици боље разумеју објекатске допуне, да своје знање о њима могу да примене и утврде, наставник може осмислити специфичан стриповни образац, конципиран тако да уз помоћ визуелних елемената и непотпуног вербалног дела наводи ученике да осмисле сопствене примере реченица и тиме допуне белине у стрипу.

5 Правилник о Наставном плану и програму за пети и шести разред основног образовања и васпитања: Српски језик. Министарство просвете и спорта Републике Србије. Просветни гласник бр. 6/2006. Предвиђено је да проверавају и систематизују знања ученика стечена у претходним разредима која се тичу овладавања простом реченицом и њеним деловима, те да се обнови знање о главним реченичним члановима (предикату, као централном реченичном члану, и субјекту, као независном члану реченице) и усвоји знање о објекту као зависном реченичном конституенту.

6 Наставнику је рад са ученицима приликом обраде сложене грађе о објекту у петом разреду утолико отежан јер се то градиво изучава пре обраде падежног система и пре сагледавања поделе глагола и глаголског рода, међутим, конкретност синтаксе омогућава да се објекат разуме и без тих знања, при чему се наставник кроз симплификације никако не сме огрешити о принцип научности (Петровачки 2008: 80-106). 
Садржај стрипа намењеног за вежбање, његову тематику и изглед илустрација треба при томе прилагодити узрасту ученика, њиховим способностима и потребама рада на часу. ${ }^{7}$ Свакако да ће визуелна присутност елемената стрипа олакшати сагледавање ситуације и мотивисати ученике на интензивнију мисаону и комуникативну активност. Илустровани кадрови стрипа у којима се отварају потребе за исказивање конструкција са објектом, подстаћи ће ученике на њихово креирање и послужити као извор информација и аспеката на основу којих ће, уз инструкције наставника, попуњавати белине, састављати остатак текста. Стриповни образац би могао бити осмишљен на следећи начин:

\footnotetext{
7 Милија Николић истиче да је „уклопљеност илустрације у саодносне везе са језичким примерима (како у говору - тако и на слици) основно начело по коме се успешно примењују илустрације у настави граматике” и додаје да илустрација никад није сама, она се здружује са исказима који јој претходе или следе те се у овиру читавог методичког приступа појављује као међупоступак. Своју снагу предаје речима" (Николић 2009: 677).
} 

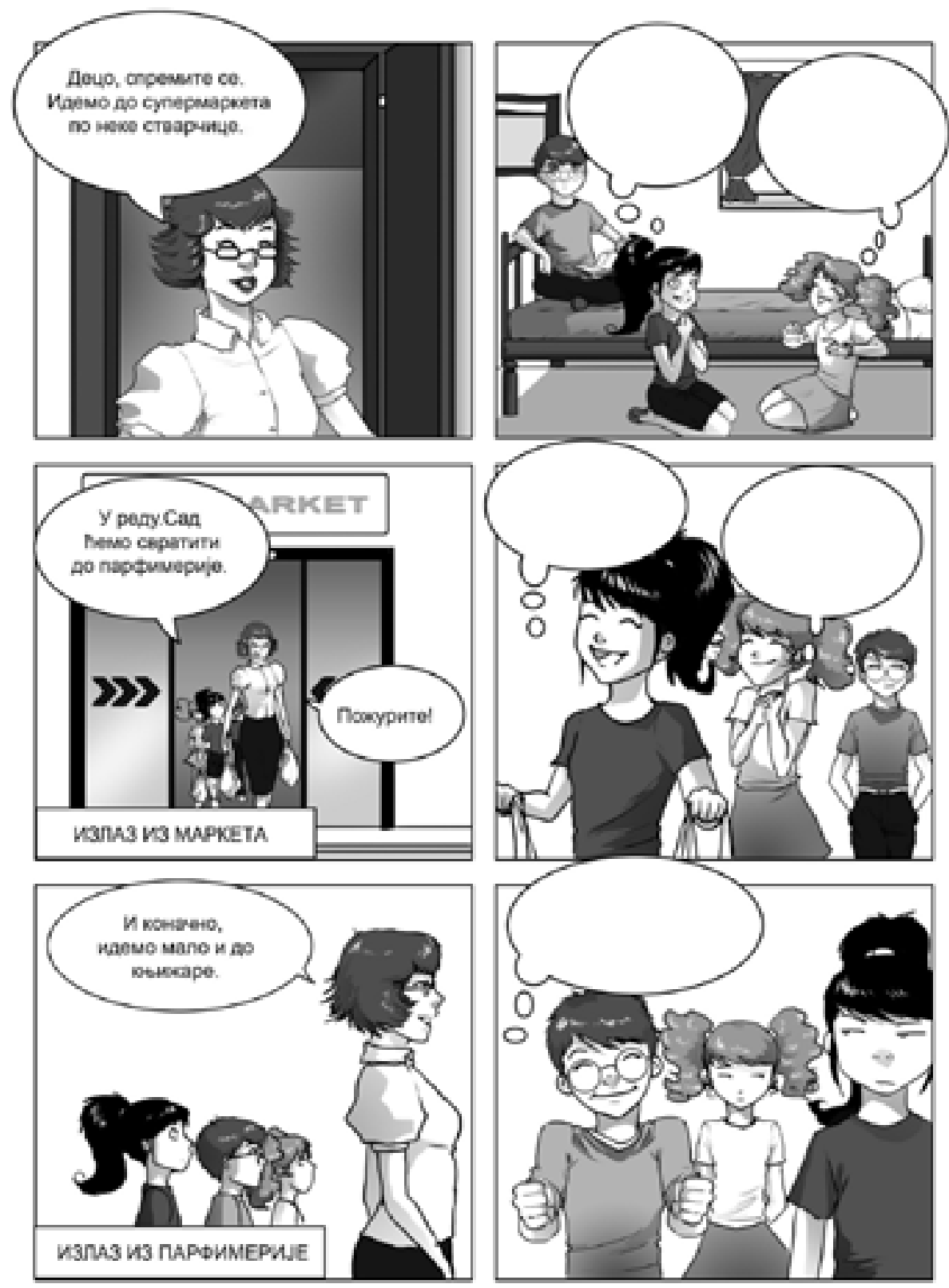

У оваквој наставној поставци свака слика представља прорачунати подстицај за разумевање одређене комуникативне 
ситуације и омогућава ученику да лакше осмисли реченицу, блиску његовом говорном искуству, која ће садржати објекат. Као резултат очекује се заокруживање знања о објекту као једном од основних реченичних конституената и његова правилна примена.

\section{4. ЗАКЉУЧАК}

Употреба стриповне форме у настави граматике као средства презентације и објашњавања одређених тема, добар је пример језичке креативности и представља један вид остваривања корелације између наставних предмета Српски језик и књижевност и Ликовна култура. С обзиром на то да су нове генерације ученика највише изложене учењу уз помоћ визуелних медија, визуелни подстицаји у комбинацији са кратким текстом за њих могу бити снажни импулс за откривање начина функционисања језика и квалитетнију комуникацију са светом који их окружује. Стога сматрамо да се стриповне секвенце понекад могу корисно употребити као наставно средство за обраду градива и из синтаксе. Њихова примена отвара нове могућности у настави, нарочито у приступу презентовања различитих комуникативних ситуација, односно реченичних конструкција, типова и модела, као што је у раду приказано.

Стриповни предложак примењив је у свим фазама часа граматике српског језика, при чему је неопходно да његова употреба буде функционална, адекватна и сврсисходна, а не да служи у забавне сврхе. Таква употреба у настави свих образовних нивоа може да мотивише ученике на проналазачке и стваралачке активности. Применом илустративно-демонстративне методе у форми стрипа у настави граматике задовољава се методички принцип очигледности који треба да је еминентан у савременом школском учењу. 


\section{ЛИТЕРАТУРА}

Илић, Павле (1998). Српски језик и књижевност у наставној теорији и пракси. Методика наставе. Нови Сад: Змај.

Николић, Милија (1999). Методика наставе српског језика и књижевности. Београд: Завод за уџбенике и наставна средства.

Петровачки, Љиљана (2004). Синтакса у настави српског језика и къижевности. Нови Сад: Змај.

Петровачки, Љиљана (2008). Методичка истраживања у настави српског језика и кьижевности. Нови Сад: Филозофски факултет. Одсек за српски језик и лингвистику.

Петровачки, Љиљана и Гордана Штасни (2010). Методички системи у настави српског језика и књижевности. Нови Сад: Филозофски факултет. Одсек за српски језик и лингвистику.

Пипер, Предраг, И. Антонић, В. Ружић, С. Танасић, Љ. Поповић, Б. Тошовић (2005). Синтакса савременог српског језика (Проста реченииа). Београд: Институт за српски језик САНУ. Београдска књига. Матица српска.

Станојчић, Живојин и Љубомир Поповић (2010). Граматика српског језика. Београд: Завод за уџбенике и наставна средства.

Тежак, Стјепко (2000). Теорија и пракса наставе хрватскога језика. Загреб: Школска књига. 
Ljiljana E. Petrovački and Milica M. Savić

\section{COMICS IN SERBIAN GRAMMAR CURRICULUM}

Summary: The paper offers an overview of possibilities regarding illustrated presentations of linguistic terms, categories, principles and rules with the use of comics in Serbian language curriculum. Ways of using additional material of that kind are presented in different phases of syntax curriculum, emphasizing the importance of the application of visual means as an illustration of a variety of communication situations. Advantages of that methodological approach are stressed with respect to the realization of principles of the obvious in teaching, so selected linguistic and grammatical material was applied to sentence constructions, models and types for which we designed and developed applications in the form of representational comic supplements.

Key words: methodology of Serbian language curriculum, additional material, comic, sentence constructions. 